Janna Linnansaari is a doctoral student in the Department of Teacher Education, University of Helsinki, Finland. Her doctoral studies will focus on the engagement of students especially in school context and science teaching and learning. Her area of interest is also experience sampling method as data collecting tool together with ICT use in school context.

Jaana Viljaranta is a post-doctoral researcher in the Department of Psychology, University of Jyväskylä, Finland. Her area of expertise is in learning motivation, especially in the role of different motivational aspects in relation to academic skill development, as well as educational and occupational plans and choices at different phases of the school career.

Jari Lavonen is a full professor of physics and chemistry education in the Department of Teacher Education, University of Helsinki, Finland. His research and development focuses on science and technology teaching and learning, science teacher education and ICT use in science and technology education.

Barbara Schneider is distinguished professor in the College of Education, Department of Sociology at Michigan State University, United States. She is the principal investigator of the College Ambition Program (CAP) that tests a model for promoting a STEM college-going culture in high schools that encourages adolescents to pursue STEM majors in college and occupations in these fields. Her research focuses on the social contexts of schools and families and their influence on academic and social wellbeing of adolescents.

Katariina Salmela-Aro is professor in psychology, University of Jyväskylä, acting professor in Cicero Learning, University of Helsinki and Visiting professor Institute of Education, University College London, UK. She is incoming President of the European Association for Developmental Psychology and Past Secretary general of the international Society for Behavioral Development.

JANNA LINNANSAARI

Department of Teacher Education

University of Helsinki, Finland

janna.linnansaari@helsinki.fi

JAANA VILJARANTA

Department of Psychology

University of Jyväskylä, Finland

jaana.h.viljaranta@jyu.fi

\section{JARI LAVONEN}

Department of Teacher Education

University of Helsinki, Finland

jari.lavonen@helsinki.fi

\section{BARBARA SCHNEIDER}

College of Education, Department of Sociology, Michigan State University, United States

bschneid@msu.edu

KATARIINA SALMELA-ARO

Department of Psychology, University of Jyväskylä,

Finland

katariina.salmela-aro@helsinki.fi

\title{
Finnish Students' Engagement in Science Lessons
}

\section{Abstract}

The decreasing number of students who are engaged in science learning has been recognised as a problem. The pre-conditions of engagement and actual engagement were examined using a novel research method to obtain detailed information on Finnish students' engagement in different situations and to gain a better understanding of this phenomenon. The study's participants consisted of 68 students (31 girls, 37 boys) from $9^{\text {th }}$ grade and 67 students (46 girls, 21 boys) from 1st grade in upper secondary school. The research aimed to answer the following question: How does Finnish students' engagement occur in exact and life science lessons? Participants received smartphones equipped with a smartphone application that included an experience sampling method questionnaire. The smartphones were programmed to emit a signal during every science lesson and otherwise randomly 
during the day (from 8 am to 8 pm). The results reveal that situation and grade had significant effects on students' pre-conditions of engagement and actual engagement. Our results also show that girls had the highest interest in life science lessons and boys in exact science lessons.

\section{INTRODUCTION}

Engagement, motivation and interest have been widely studied in the fields of psychology and education (e.g. Eccles \& Wang, 2012; Fredricks, Blumenfeld \& Paris, 2004; Fredricks \& McColskey, 2012; Upadayaya \& Salmela-Aro, 2013; Viljaranta, Nurmi, Aunola \& Salmela-Aro, 2009). Moreover, students' engagement and interest has been studied in science lessons (e.g. DeBacker \& Nelson, 200o; Kumar, 1991; Osborne, Simon \& Collins, 2003), especially in physics (e.g. Bennett, 2005; Lavonen, Meisalo, Byman, Uitto \& Juuti, 2005). Osborne et al. (2003) argue that students' interest in, motivation and attitudes towards school science and their beliefs as learners are important for their engagement in science learning and can have positive effects on the quantity and quality of learning outcomes. However, students' situational engagement in science lessons has rarely been examined as a way of identifying the pre-conditions of engagement and the level of engagement. Students behave differently in various science subjects; therefore, we divided the latter into two categories: chemistry and physics as the exact science subjects and biology as a life science subject.

One widely adopted approach is to define engagement in the context of the flow theory. According to Csikszentmihalyi (1990), flow is an optimal experience which includes a deep sense of enjoyment. These moments are not passive and seem to occur when a person stretches body or mind to its limits in a voluntary effort to gain something difficult or worthwhile-in other words, challenging. Flow entails the attempt to achieve a goal because it is intrinsically rewarding (Csikszentmihalyi, 1990). To achieve flow, students must have high levels of skill and (situational) interest and be challenged by the task, elements which are considered pre-conditions for flow. This definition of engagement has been expanded to include (situational) interest from flow theory (Csikszentmihalyi, 1997). If these pre-conditions are present, students can enter flow state. The relationship between pre-conditions and engagement is shown in Figure 1 and was based on the literature review conducted by principal investigation (PI) Barbara Schneider during Eager Project ${ }^{1}$.

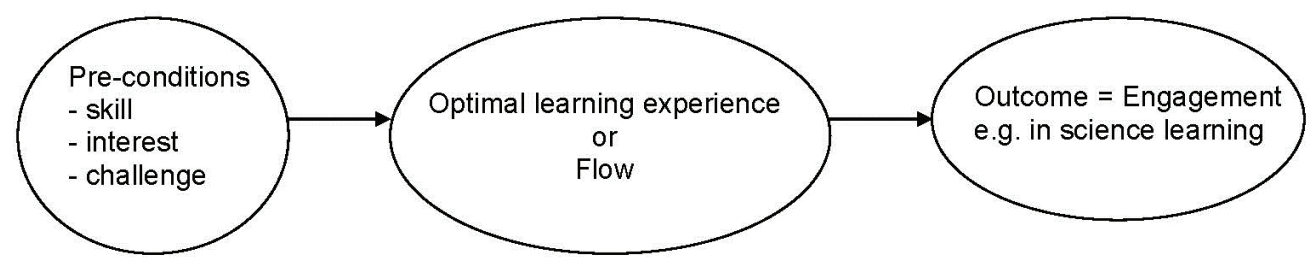

Figure 1. Pre-conditions of engagement, optimal learning experience and engagement.

Previous studies (e.g. Jimerson, Campos \& Greif, 2003; Schaufeli, Martínez, Pinto, Salanova \& Bakker, 2002) typically were conducted using surveys in which students were asked to recall science learning situations. To obtain detailed information on pre-conditions which lead students to be engaged in the science classroom, we believed that their engagement should be measured immediately when it occurs. Therefore, in this study, we assumed that more authentic and detailed measurements could be captured with the experience sampling method (ESM) and smartphones. We employed a novel research method, along with a questionnaire used in the Eager Project ${ }^{1}$. Our aim was to find out how Finnish students' engagement occurs in exact (chemistry and physics) and life sciences (biology). To

1 The Eager Project is a collaborative international project (2013-2015) funded by the Finnish Academy (€200,000) and the National Science Foundation (US\$299,766). 
do so, we compared pre-conditions of engagement and actual engagement for student participants grouped by gender and grade in different situations, using z-scores for the means (M) and standard deviations (SD), Pearson's correlations and multivariate analysis of variance (MANOVA).

\section{Pre-conditions of engagement}

According to previous studies, students' interest is an important factor in predicting their engagement and learning outcomes (Singh, Granville \& Dika, 2002). Interest in a task seems to occur when students enjoy performing it, and it is combined with optimal cognitive experiences, for example, students' belief that the task is meaningful for them (Krapp, 2002; Schiefele, 1992). A contradiction has been found between students' interest in science in general and in school science in particular (Osborne et al., 2003). Both teachers and students perceive the value of science and technology as essential aspects of contemporary society and the future which make our lives healthier, easier and more comfortable and our work more interesting (Oscarsson, Jidesjö, Strömdahl \& Karlsson, 2009). At the same time, students consider school science uninteresting but acknowledge the value both of science itself and of different science subjects. For example, secondary school students' main reason for studying chemistry is to prepare for their postgraduate studies and working life (Vesterinen, Aksela \& Rantaniitty, 2013).

The concept of interest can be approached from two major viewpoints: interest as a characteristic of a person (personal interest) and interest as a psychological state aroused by specific characteristics of the learning situation (situational interest). Situational interest is spontaneous, fleeting and shared among individuals. It is an emotional state evoked suddenly by something in the immediate environment and might have only a short-term effect on an individual's knowledge and values (see more Schraw \& Lehman, 2001). When interest is measured by surveys, the outcomes more reflect personal than situational interest because after a certain situation, it is challenging to recall one's own feelings (Schiefele, 1999). However, our study offers a new way to collect information also from situational interest.

Students' self-evaluation of their skills plays a role in investigating their engagement and motivation. In an ideal situation when so-called meaningful learning occurs, students are engaged in tackling the topic of the lesson in a way that creates significant and understandable knowledge structures based on the learning goals (Lavonen, Krzywacki, Koistinen, Welzel-Breuer \& Erb, 2012). Students' motivation emerges when they believe they are able, in other words, they have the skills to succeed at a given task (Brophy, 2008). Additionally, providing students with appropriate challenges and opportunities to enhance their skills can be considered one of the most important ways of engaging them (Shernoff, Csikszentmihalyi, Schneider \& Shernoff, 2003). In this study, students' skills are interpreted as selfefficacy (Lavonen \& Laaksonen, 2009), including feelings of competence and control. Self-efficacy refers to individuals' beliefs in their ability to produce a desired effect through their actions (Bandura, 1994), such as completing an on-going task. In this case, they have incentive to undertake similar activities and persevere in the face of difficulties in the future (Bandura, 1994).

For students to be engaged, their skills cannot be overmatched or underutilised by the challenge presented by the on-going task (Csikszentmihalyi, 1997). The concept of a challenge can be defined through the biopsychosocial model of challenge and threat (Blascovich, Seery, Mugridge, Norris \& Weisbuch, 2004; Seery, 2011). A challenge seems to be a relatively positive state in which an individual's resources meet or exceed the demands of the task. In contrast, a threat can be regarded as a negative psychological state in which the task's demands exceed the individual's resources. A challenge is proposed to be associated with positive emotions, increased energy levels and dedication to the task (Meijen, Jones, McCarthy, Sheffield \& Allen, 2013). In a learning activity, students are more likely to show higher level of achievement when facing a difficult challenge (Grant \& Dweck, 2003). 


\section{Optimal learning experience}

An optimal learning experience or flow seems to occur in situations when demands (challenges) and resources (skills) are both high (Csikszentmihalyi \& Schneider, 2000). In addition, the challenge offered by the on-going task and individuals' skills should be balanced so that individuals stretch their skills to the limit in order to achieve a challenging goal (Shernoff \& Csikszentmihalyi, 2009). Flow is only one outcome of the combination of challenges and skills. Other possible outcomes are apathy (low challenge, low skills), anxiety (high challenge, low skills) and relaxation (low challenges, high skills) (Csikszentmihalyi, 1997). The benefit of flow theory is that it is not unique to a single domain (Csikszentmihalyi, 1990). Flow state can occur not only during different tasks but also in business and free-time activities, such as sports. In this research, we attempted to catch moments in which students are in flow state in exact science, life science and other lessons at school. Given the school context, students were deemed to have an optimal learning experience. We also measured students flow state experiences outside school.

\section{Gender and grade differences in science learning}

Research on student interest and motivation has revealed that science generally is interesting for students, but most students, especially girls, do not find school science and technology or careers and occupations in these fields interesting (Bennett, Hogarth \& Lubben, 2005; Krapp \& Prenzel, 2011; Tytler, Osborne, Williams, Tytler \& Cripps, 2008). According to Osborne et al. (2008), studies have shown that boys consistently have a more positive attitude to school science compared to girls. However, this gender difference is ambiguous. Gender differences in science learning can be explained by various reasons, such as differences in class experiences (Griffth, 2010), a lack of opportunities to actively participate in science (Osborne et al., 2003) and community norms that reinforce traditional gender roles in science (Riegle-Crumb \& Moore, 2014).

Previous studies showed variations in how different students experience science teaching and learning. Gender differences can also be found in different science subjects. For example, girls usually are more interested in biology than in physics, while for boys, the opposite is true (Fairbrother, 2000; Lavonen \& Laaksonen, 2009). However, in chemistry, the situation is more complex. Different studies have shown that girls have more positive attitudes towards chemistry than boys (e.g. Steinkamp \& Maehr, 1984) and the opposite situation (e.g. Barnes, McInerney \& Marsh, 2005). Gender differences also seem to be influenced by the learning method and the content of the lesson (Cheung, 2009). In biology, students' success corresponds with their positive attitudes (Uitto, 2014), self-efficacy and interest and the subject's importance (Uitto \& Kärnä, 2014).

There has been evidence of decreasing level of positive attitudes towards and interest in school science as students move from primary to secondary school (Gonzales, Williams, Jocelyn, Roey, Kastberg \& Brenwald, 2008; Greenfield, 1997). Some studies have also shown that students' achievement in science subjects decreases as their grade level increases (Bursal, 2013). This trend might occur partly because the content of science subjects become harder for students based on the curriculum and time available for different contexts.

\section{Measuring students' engagement}

Students' engagement in a given situation usually has been measured with paper-and-pencil questionnaires (e.g. Fullan, 2007; Wigfield \& Gambria, 2010) and observation (e.g. Malmberg, Hagger, Burn, Mutton \& Colls, 2010). It can also be measured with ESM (e.g. Csikszentmihalyi \& Larson, 1987; Hektner, Schmidt \& Csikszentmihalyi, 2007). Compared to conventional research methods, ESM enables researchers to concentrate on situations in which engagement occurs. In this research, ESM was employed through smartphone technology. Smartphones and ESM have been used in research with adults and university students (e.g. Muukkonen, Hakkarainen, Inkinen, Lonka \& SalmelaAro, 2008; Tolvanen et al., 2011). 
In this study, we investigated Finnish students' engagement in science classrooms, distinguishing between the exact and the life sciences. In this study we were interested in students' engagement in different situations rather than in different context of the school subjects. We used a novel research method that allowed us to obtain detailed information on students' engagement in various situations. Considering the small sample size, we employed a more exploratory research approach. Our aim was to use ESM to look at how situational engagement occurs among Finnish students in different situations.

The research questions were:

- How does Finnish students' engagement occur in exact and life science lessons based on measurements of students' pre-conditions of engagement and actual engagement?

- Are there differences in students' engagement according to gender, grade or type of situation measured?

\section{METHOD}

This study was part of the collaborative Finnish-American Eager Project. The questionnaire used in this study was designed in collaboration with researchers from Michigan State University and the University of Helsinki and based on similar protocols as those used in the Sloan Study of Youth and Social Development (for details, see Csikszentmihalyi \& Schneider, 2000).

\section{Research instrument}

\section{Experience sampling method}

ESM has been used to observe students' consciousness, thoughts, feelings and other sensations which are hard to measure (Hektner et al., 2007) taking into account individuals' changes over time and differences between individuals in a group (Bolger, Davis \& Rafaeli, 2003). The baseline of ESM is that data collection lasts 7 days, participants receive 7-10 daily signals, the minimum time between two signals is 15 minutes, and completing an ESM questionnaire takes 2 minutes (Csikszentmihalyi \& Larson, 1987).

\section{Experience sampling method questionnaire}

To obtain comparable information about students' engagement, the ESM questionnaire began with the open-ended question 'Where are you?'. This question made it possible to compare students' answers according to the situation. Students' answers were grouped to be life science, exact science, other lessons and other situations. Items that measured students' pre-conditions of flow state and engagement consisted of four-point, Likert-scale questions, with the extreme categories of 'not at all' and 'very much'.

Five questions assessed students' skills (Do you have skills in this activity? Are you succeeding? Do you feel capable? Do you feel in control? Do you feel competent in this activity?). Two questions determined students' interest in the task (Is this activity interesting? Do you enjoy what you are doing?). The challenge presented by the task was gauged with a single question (Does the activity present a challenge?). The sums for skills and interest were calculated, along with the z-scores of the sums for further analysis. Engagement was operationalised as the sum of the z-scores for skills (sum), interest (sum) and challenge. Students were considered to be engaged when all the z-scores were positive, showing that students' values for these pre-conditions were above average. Otherwise, students were deemed to be not engaged. To test the reliability of the sums, Cronbach's alphas were calculated using the questions that belonged to an item.

Table 1 shows formulation of the questions used in this research and the Cronbach's alphas for sums. 
Table 1. Formulation of the questions used and the Cronbach's alphas for sums.

\begin{tabular}{|l|l|c|}
\hline & Question & Cronbach's Alpha \\
\hline Skills & $\begin{array}{l}\text { Do you have skills in this activity? } \\
\text { Are you succeeding? } \\
\text { Do you feel capable? } \\
\text { Do you feel in control? } \\
\text { Do you feel competent in this activity? }\end{array}$ & \\
\hline Interest & $\begin{array}{l}\text { Is this activity interesting? } \\
\text { Do you enjoy what you are doing? }\end{array}$ & \\
\hline Challenge & Does the activity present a challenge? & .81 \\
\hline Engagement & $\begin{array}{l}\text { Sum of skills } \\
\text { Sum of interest } \\
\text { Does the activity present a challenge? }\end{array}$ & \\
\hline
\end{tabular}

\section{Data collection}

The study was conducted during 2 weeks in the spring of 2013 and 1 week in the fall of 2013. Altogether, 68 students ( 31 girls, 37 boys) in the $9^{\text {th }}$ grade and 67 students ( 46 girls, 21 boys) in the 1st grade in upper secondary school participated in the study. The participants were selected from 2 schools which had already co-operated with the University of Helsinki. Before data collection, the study's purpose was explained to principals, teachers, students and their parents, and permission was obtained from them.

At the beginning of the study, the researchers visited both schools. The students received smartphones equipped with the Paco application (created by a Google engineer) and the ESM questionnaire, which aimed to immediately measure students' engagement in different situations. The phones were programmed to emit a signal during every science lesson and otherwise randomly throughout the day (from 8 am to $8 \mathrm{pm}$ ) so that the ESM questionnaire appeared 8 times per day. The students were guided on how to answer the ESM questionnaire. After each signal, they were allowed 15 minutes to answer the ESM questionnaire. If the students were unable to answer the questionnaire at a specific time for any reason, they were advised to continue with the next one. The questionnaire was the same throughout data collection. The students' answers on the ESM questionnaire were transferred to the Paco application's webpage after the smartphone was connected to the Internet. From the Paco webpage, students' answers were delivered to IBM SPSS Statistics 22 using the comma-separated values (CSV) format. Each student received an individual identification number from researchers, which enabled combining students' answers in different situations.

\section{Data analysis}

In this study, students' pre-condition of engagement and actual engagement were examined. To identify possible differences among groups, participants were divided by gender and grade. The situations in which students answered the ESM questionnaire were coded as follows: $1=$ exact science, $2=$ life science, $3=$ other lessons and $4=$ other situations. To estimate students' overall level of engagement in the classroom, the raw ESM scores were converted into $z$ scores. The standardised $z$ scores were also added to the analysis because of their greater sensitivity to the effect of the context on students' quality of experience (Shernoff et al., 2003). The standardised $z$ scores enabled examining 
each student's individual experiences throughout the week. The $z$ scores for pre-conditions indicated how students' answers were connected with one another. In other words, a o score was considered an average value of a pre-condition; a deviation, either positive or negative, showed how much students' pre-conditions deviated from their general answers. To explore how students' pre-conditions of engagement and actual engagement varied, we examined means (M) and standard deviations (SD) using $z$ - scores. The students' answers could be treated as independent variables; therefore, we focused on the interaction between gender, grades and situations. Students' scores were converted to $z$ scores, and MANOVA was used as the primary statistical test (compare to Shernoff et al., 2003). We used gender, grade and situation as the independent variables, and the pre-conditions of engagement and actual engagement as the dependent variables. The participants gave a total of 3,683 answers in response to the incoming signals for data collection, with an average response rate of 40.5 per student (with the number of answers at 22.7). To assess the relationship between different factors (gender, grade and type of situation) and students' pre-conditions of engagement and actual engagement, Pearson's correlations were calculated, and MANOVAs were conducted.

\section{RESULTS}

Students were grouped by gender ( $0=$ female, $1=$ male) and grade $\left(9^{\text {th }}\right.$ or 1 st in upper secondary school). Different situations were grouped according to students' answers to the 'Where are you?' question, while life and exact sciences were coded using students' school schedule.

Table 2 shows students' individual $z$ scores for the pre-conditions of engagement and actual engagement according to gender, grade and type of situation. In Table 2, a $z$ score of o represents students' average stage. A $z$ score higher than $\mathrm{o}$ indicates that students showed a high level of skill, interest, challenge or engagement, while a $z$ score less than o a low level. We used z scores to identify individual differences.

Table 2. Means (M) and standard deviations (SD) for students' engagement and pre-conditions of engagement according to gender, grade and situation (z scores).

\begin{tabular}{|c|c|c|c|c|}
\hline & $\begin{array}{l}\text { 9th } \\
\text { Girls }\end{array}$ & Boys & $\begin{array}{l}\text { 1st } \\
\text { Girls }\end{array}$ & Boys \\
\hline \multicolumn{5}{|l|}{$\begin{array}{l}\text { Exact science } \\
\text { Pre-conditions }\end{array}$} \\
\hline $\begin{array}{l}\text { z:Skill } \\
z \text { : Interest } \\
z: \text { Challenge } \\
z \text { : Engagement }\end{array}$ & $\begin{array}{l}-.224(1.01) \\
-.262(.877) \\
.383(1.01) \\
-.080(.895)\end{array}$ & $\begin{array}{l}.040(.883) \\
.027(.946) \\
.263(1.01) \\
.100(1.12) \\
\end{array}$ & $\begin{array}{l}-.406(1.07) \\
-.092(.937) \\
.541(1.07) \\
.010(1.01) \\
\end{array}$ & $\begin{array}{l}.009(.980) \\
.168(.938) \\
.656(.904) \\
.594(1.48) \\
\end{array}$ \\
\hline \multicolumn{5}{|l|}{$\begin{array}{l}\text { Life science } \\
\text { Pre-conditions }\end{array}$} \\
\hline $\begin{array}{l}\text { z:Skill } \\
z \text { : Interest } \\
z: \text { Challenge }\end{array}$ & $\begin{array}{l}.200(.841) \\
.025(1.01) \\
.138(.969) \\
.082(1.11)\end{array}$ & $\begin{array}{l}-.062(.940) \\
-.260(.863) \\
-.015(.956) \\
-.204(.676)\end{array}$ & $\begin{array}{l}-.201(.744) \\
.170(.742) \\
.256(.770) \\
.258(1.26)\end{array}$ & $\begin{array}{l}-.062(.876) \\
.460(.861) \\
-.273(.682) \\
-.350(.000)\end{array}$ \\
\hline
\end{tabular}




\begin{tabular}{|c|c|c|c|c|}
\hline & $\begin{array}{l}\text { 9th } \\
\text { Girls }\end{array}$ & Boys & $\begin{array}{l}\text { 1st } \\
\text { Girls }\end{array}$ & Boys \\
\hline \multicolumn{5}{|l|}{$\begin{array}{l}\text { Other lessons } \\
\text { Pre-conditions }\end{array}$} \\
\hline $\begin{array}{ll}\text { z:Skill } \\
z: \text { Interest } \\
z: \text { Challenge } \\
z \text { : Engagement }\end{array}$ & $\begin{array}{l}-.137(1.03) \\
-.304(.970) \\
.241(.991) \\
-.039(.095) \\
\end{array}$ & $\begin{array}{l}-.269(1.00) \\
-.335(.874) \\
.202(1.00) \\
-.107(.852) \\
\end{array}$ & $\begin{array}{l}-.269(1.00) \\
-.335(.874) \\
.202(1.00) \\
.031(1.04) \\
\end{array}$ & $\begin{array}{l}-.057(.834) \\
-.083(.943) \\
.476(.880) \\
.151(1.17)\end{array}$ \\
\hline \multicolumn{5}{|l|}{$\begin{array}{l}\text { Other situations } \\
\text { Pre-conditions }\end{array}$} \\
\hline $\begin{array}{l}z \text { z:Skill } \\
z \text { : Interest } \\
z: \text { Challenge } \\
z \text { : Engagement }\end{array}$ & $\begin{array}{l}.409(1.00) \\
.191(1.08) \\
-.380(.990) \\
-.082(.888)\end{array}$ & $\begin{array}{l}.037(1.10) \\
.287(1.01) \\
-.278(.912) \\
-.127(.817)\end{array}$ & $\begin{array}{l}-.019(1.01) \\
.082(1.01) \\
-.132(.964) \\
.037(1.01)\end{array}$ & $\begin{array}{l}.164(.882) \\
.177(.980) \\
-.363(.912) \\
-.021(.975)\end{array}$ \\
\hline
\end{tabular}

Pearson's product-moment correlation coefficients explored the relationships of gender, grade and situation to the pre-conditions of engagement and actual engagement. Pearson's correlations are shown in Table 3.

Table 3. Pearson's correlation for gender, grade and situation.

\begin{tabular}{|l|c|c|c|c|}
\hline & Skill & Interest & Challenge & Engagement \\
\hline Gender & .013 & .024 & -.032 & -.011 \\
\hline Grade & $-.073^{* *}$ & -.001 & .032 & $.059^{* *}$ \\
\hline Situation & $-.136^{* *}$ & $-.141^{* *}$ & $.218^{* *}$ & .014 \\
\hline
\end{tabular}

${ }^{* *} p \leq .001$; Correlations were calculated using all participants' ESM answers for a total of 3,683 answers.

A Pearson product-moment correlation was found to be statistically significant $-r(3131)=-.073, p$ $<.001$ and $\mathrm{r}(3118)=.059, \mathrm{p}=.001-$ indicating a strong negative relationship between grade level and skill and a strong positive relationship between grade level and engagement. A second Pearson correlation was found to be statistically significant $-\mathrm{r}(3131)=-.136, \mathrm{p}<.001, \mathrm{r}(3583)=-.141, \mathrm{p}<$ .001 and $\mathrm{r}(3614)=.218, \mathrm{p}<.001-$ indicating a strong negative relationship of situation and skill to situation and interest and a strong positive correlation between situation and challenge. In addition, we used MANOVAs to conduct statistically significant differences analysing the background variables of grade and situation separately. Table 4 shows how grade level was entered into a MANOVA as the dependent variable. Pillai's criterion was used because it is robust and appropriate for situations with unequal sample sizes. The multivariate test statistic was significant: $\mathrm{F}(4,3113)=11.862$, $\mathrm{p}<.001$, $\eta^{2}=.015$. 
Table 4. Univariate effects for grade (at $p<$. oo1 level).

\begin{tabular}{|c|c|c|c|c|c|c|c|}
\hline & \multirow[b]{2}{*}{$d f$} & \multirow[b]{2}{*}{ df error } & \multirow[b]{2}{*}{$\mathbf{F}$} & \multirow[b]{2}{*}{ Grade } & \multirow[b]{2}{*}{ Means } & \multicolumn{2}{|c|}{$99.9 \%$ Confidence interval } \\
\hline & & & & & & $\begin{array}{l}\text { Lower } \\
\text { bound }\end{array}$ & $\begin{array}{l}\text { Upper } \\
\text { bound }\end{array}$ \\
\hline \multirow{2}{*}{ Skill } & \multirow{2}{*}{1} & \multirow{2}{*}{17.247} & \multirow{2}{*}{17.411} & 9th & .090 & -.003 & .182 \\
\hline & & & & 1st & -.062 & -.138 & .014 \\
\hline \multirow{2}{*}{ Interest } & \multirow{2}{*}{1} & \multirow{2}{*}{1.812} & \multirow{2}{*}{1.821} & 9th & -.012 & -.105 & .081 \\
\hline & & & & 1st & .037 & -.039 & .113 \\
\hline \multirow{2}{*}{ Challenge } & \multirow{2}{*}{1} & \multirow{2}{*}{4.436} & \multirow{2}{*}{4.431} & 9th & -.060 & -.153 & .033 \\
\hline & & & & $1 s t$ & .017 & -.059 & .093 \\
\hline \multirow{2}{*}{ Engagement } & \multirow{2}{*}{1} & \multirow{2}{*}{10.724} & \multirow{2}{*}{$10.75^{8}$} & 9th & -.071 & -.164 & .021 \\
\hline & & & & 1st & .048 & -.028 & .124 \\
\hline
\end{tabular}

Significant univariate effects were found for grade and skill $(\mathrm{F}(1,17.247)=17.411 \mathrm{P}<.001)$ and for grade and engagement $(\mathrm{F}(1,10.724)=10.758, \mathrm{p}=.001)$. The results for grade and interest and for grade and challenge were not significant.

Table 5 presents the results from entering situation into a MANOVA as a dependent variable. Pillai's criterion was used, and the multivariate test statistic was significant $(\mathrm{F}(12,9339)=28.455, \mathrm{p}<.001$, $\left.\eta^{2}=.035\right)$.

Table 5. Univariate effects for situation (at $p<.001$ level).

\begin{tabular}{|c|c|c|c|c|c|c|c|}
\hline & \multirow{2}{*}{ df } & \multirow{2}{*}{ df error } & \multirow{2}{*}{$\mathbf{F}$} & \multirow{2}{*}{ Situation } & \multirow{2}{*}{ Means } & \multicolumn{2}{|c|}{$\begin{array}{l}99.9 \% \text { Confidence } \\
\text { interval }\end{array}$} \\
\hline & & & & & & $\begin{array}{l}\text { Lower } \\
\text { bound }\end{array}$ & $\begin{array}{l}\text { Upper } \\
\text { bound }\end{array}$ \\
\hline \multirow{4}{*}{ Skill } & \multirow{4}{*}{3} & \multirow{4}{*}{23.593} & \multirow{4}{*}{24.223} & Exact science & .129 & .051 & .206 \\
\hline & & & & Life science & -.212 & -.399 & -.026 \\
\hline & & & & Other lessons & -.060 & -.282 & .162 \\
\hline & & & & Other situation & -.180 & -.292 & -.068 \\
\hline \multirow{4}{*}{ Interest } & \multirow{4}{*}{3} & \multirow{4}{*}{28.231} & \multirow{4}{*}{29.138} & & .147 & .070 & .224 \\
\hline & & & & & -.101 & -.296 & .085 \\
\hline & & & & & .078 & -.144 & .299 \\
\hline & & & & & -.227 & -.339 & -.115 \\
\hline \multirow{4}{*}{ Challenge } & \multirow{4}{*}{3} & \multirow{4}{*}{79.926} & \multirow{4}{*}{86.300} & & -.250 & -.326 & -.174 \\
\hline & & & & & .447 & .265 & .628 \\
\hline & & & & & .115 & -.102 & .332 \\
\hline & & & & & .282 & .173 & .392 \\
\hline \multirow{4}{*}{$\begin{array}{l}\text { Engage- } \\
\text { ment }\end{array}$} & \multirow{4}{*}{3} & \multirow{4}{*}{.084} & \multirow{4}{*}{.834} & & -.020 & -.099 & .058 \\
\hline & & & & & .060 & -.128 & .249 \\
\hline & & & & & .055 & -.170 & .280 \\
\hline & & & & & .006 & -.108 & .120 \\
\hline
\end{tabular}


Significant univariate effects were found for situation and skill $(\mathrm{F}(3,23.593)=24.223, \mathrm{p}<.001)$, for situation and interest $(\mathrm{F}(3,28.231)=29.138, \mathrm{p}<.001)$ and for situation and challenge $(\mathrm{F}(3,79.926)$ $=86.300, \mathrm{p}=.001)$. The results for situation and engagement were not significant.

\section{Discussion AND CONCLUSIONS}

Our aim was to explore how Finnish students' engagement occurs during exact and life science lessons and how it varies according to gender, grade and situation. Given the small sample size, we used an exploratory method to investigate students' pre-conditions of engagement and actual engagement in various situations. We used a novel data collection method, which allowed us to collect more than 3,600 answers about students' engagement in different situations as it occurred. By using this method, we were able to capture students' engagement immediately in the situation at hand, instead of using a survey later to ask them about their more general engagement. The data obtained from this study reveal a number of interesting findings, and our study provides new information from science classrooms, focusing on students' engagement and its pre-conditions at the exact moment they occur. Previous studies typically concentrated either on factors behind students' attitudes and motivation in science classrooms or on the contents and context that motivated or engaged students (Bennett et al., 2005; Lavonen, Byman, Uitto, Juuti \& Meisalo, 2008a; Osborne et al., 2003).

To be engaged, students need to have high levels of interest, skills and challenges. Our aim was to find out how these pre-conditions occurred for students daily over one week. We were interested in students' situational interest, which is a psychological state that is aroused by specific characteristics of the learning situation (Krapp, 2002), is changeable and is partly under control of teachers (Schraw \& Lehman, 2001). According to previous research in Finland, there is a difference between students' interest in science and in school science (Lavonen et al., 2008a; Lavonen et al., 2008b). Our results reveal that students' situational interest in science lessons was not as uniform as in other lessons. In both grades, girls tended to be interested in life science lessons and uninterested in exact science lessons. In contrast, boys in both grades were highly interested in exact science topics but not life sciences. Our results are in line with those from previous studies in which girls seemed to be more interested in biology than in physics (Lavonen \& Laaksonen, 2009). In previous studies, physics has been considered uninteresting because it is difficult, irrelevant and boring for some students, especially girls (Williams, Stanisstreet, Spall, Boyes \& Dickson, 2004). Oon and Subramianiam (2010) conducted a study focusing on the declining interest in physics from teachers' perspective. According to the results, teachers feel that physics is difficult and abstract to students, and the perception that physics is for boys seems to arise from society (Oon \& Subramianiam, 2010). Previous studies have also presented girls as more interested in biology than boys. For example, a study on students in Israel pointed out that, even though students' overall interest in biology was relatively positive but not high, girls showed greater interest in it than boys (Trumper, 2006), in line with the findings of this study. In addition, students' level of interest in biology correlated to their negative opinions of science lessons (Trumper, 2006).

Students' interest in science subjects has been measured in different national and international contexts through surveys. Lavonen et al. (2005) revealed that science topics were interesting, especially in the case of girls, if they were connected to human beings. Similar results have been found when examining students' interest in biology. According to Uitto, Juuti, Lavonen and Meisalo (2006), boys were more interested in basic processes in biology, whilst girls found human biology more interesting. In our results measuring students' situational interest using $z$ scores, girls as a group were more interested in life sciences and boys in exact sciences. In our study, we did not control what happened in the class during data collection, so the contents of the lessons could have been more optimal for girls than boys. Our study revealed that boys' interest in science varied according to grade level. However, there was no pattern of decline or increase in students' interest. According to Hong, Shim and Chang (1998), interest level among middle school students was highest among eighth graders. 
Another pre-condition which we observed was skills, which were defined to include students' selfefficacy, control of the situation and feeling of competence necessary in the situation. Students' skills play important roles in their motivation and engagement (Brophy, 2008). When students' perceive themselves as having the required skills, they are encouraged to undertake similar activities in the future (Bandura, 1994). Our results reveal that girls as a group evaluated their skills as above average in $9^{\text {th }}$-grade life science lessons and below average in exact science lessons in both grades. Boys, on the other hand, evaluated their skills as above average in exact sciences and below average in life sciences. Programme for International Student Assessment survey data from 2006 showed a somewhat similar result: Boys' science-related self-efficacy was higher than that of the girls (Lavonen \& Laaksonen, 2009). According to another study focusing on Finnish students and their motivational orientations in science (Lavonen et al., 2008), boys perceived science as a little easier compared to girls. This result can be interpreted to indicate boys more highly evaluated their skills in science than girls. In the present research, grade, not gender, had a significant correlation with students' skills.

The third pre-condition is challenge. Challenge is an important factor for engagement. When students encounter a challenge that can be overcome, the feeling of a challenge can arouse positive emotions and increase the levels of energy and dedication to the task (Meijen et al., 2013). The most notable, important finding for science education was that boys did not seem to be engaged in life science lessons nor girls in exact science lessons. Students' level of challenge has a relationship to effective learning strategies and students' mastery goals (Ames \& Archer, 1988). Furthermore, students' feelings of positive challenges, meaningful lessons and engagement seem to be related (Shernoff et al., 2003). According to our results, grade had a small, significant difference with challenge. However, situation had the strongest correlation with pre-conditions of engagement.

When planning the content of science subjects, science educators should take into account how to support students' self-efficacy, increase their interest and offer appropriate challenges. These three pre-conditions can be seen as a bridge to engage students in learning science. This research has demonstrated that ESM can be used to gather information from various situations. In addition, students' situational evaluation of their feelings and thoughts enables teachers to examine more closely, for instance, how different teaching methods engage students in the lessons.

The most important result for science teachers and educators is the need to know when and how students can achieve an optimal learning experience. The optimal learning experience, or flow state, is important for learning because in this state, students perceive their performance as pleasurable and successful (Nakamura \& Csikszentmihalyi, 2002). Our results reveal interesting findings about engagement. In both grades, girls were engaged in various situations in life science lessons and boys in various situations in exact science lessons. Students in the 1st grade of upper secondary school had a higher level of engagement than $9^{\text {th }}$ graders. However, there were lessons in which students as a group did not engage at all. Among $9^{\text {th }}$-grade girls, these were exact science lessons, and among boys in both grades, these were life science lessons. In science education, it is highly important to find a way to engage students because of the declining level of science orientation (Osborne et al., 2003). It is important to recognise that most previous measurements of interest were operationalised through surveys; in contrast, we gauged interest in authentic learning situations through ESM and smartphones. Therefore, the findings of the survey assessments are consistent with those of ESM measurements in specific situations.

\section{LIMITATIONS AND RECOMMENDATIONS}

Some limitations should be taken into account when interpreting our results. The sample included only two schools that had worked with the University of Helsinki and whose students were used to participating in different kinds of research. As well, students in both schools had performed well in science subjects. To obtain additional evidence of students' situational engagement, this study should 
be replicated and include a greater number of schools and students from different areas. In addition, students' general engagement could be studied through a background questionnaire, whose results could be compared to those for students' situational engagement. In this research, we did not use other methods to support students' given answers, a limitation which could be addressed in future research. Combining students' questionnaires, interviews or video recordings with the ESM questionnaire could more accurately measure students' general and situational engagement and could improve the reliability of the study.

The validity and reliability of ESM can be examined through quantitative analysis, interviews or questionnaires investigating how students and teachers feel about ESM (see more Csikszentmihalyi \& Larson, 1987). The reliability of ESM could be analysed by dividing the week in half and looking for consistency in the answers, using the means and standard deviation and examining the sampling accuracy. Validity could be examined by focusing on the situational validity of the answers, the characteristics and variation of experiences and the differences in experiences between groups. Validity and reliability of this study will be discussed in a future paper. However, our results have shown that ESM is a valid method for measuring students' situational engagement.

\section{ACKNOWLEDGEMENTS}

The authors would like to acknowledge the valuable comments and suggestions of the reviewers which improved the quality of this paper. This research is part of the Eager Project and is one of the Science Across Virtual Institutions' international projects funded by the Academy of Finland (No. 265915) through a grant to Jari Lavonen, Katariina Salmela-Aro and Janna Linnansaari and by a National Science Foundation (DRL-1255807) grant awarded to Barbara Schneider. The work of Jaana Viljaranta was financed by personal funding from the Academy of Finland (No. 265817).

\section{REFERENCES}

Ames, C., \& Archer, J. (1988). Achievement goals in the classroom: Students' goals in the classroom: Students' learning strategies and motivation processes. Journal of Educational Psychology, $80(3), 260-267$.

Bandura, A. (1994). Self-efficacy. In V. S. Ramachaudran (Ed.), Encyclopedia of human behavior, (Vol. 4, pp. 71-81). New York: Academic Press.

Barnes, G., McInerney, D. M., \& Marsh, H. W. (2005). Exploring sex differences in science enrolment intentions: an application of the general model of academic choice. Australian Educational Researcher, 32(2), 1-23.

Bennett, J. (2005). Teaching and learning science: a guide to recent research and its applications. London: Continuum.

Bennett, J., Hogarth, S., \& Lubben, F. (2005). A systematic review of the effects of context-based and science-technology-society (STS) approaches in the teaching of secondary science. Department of Educational Studies: Research Paper 2005/02. University of York.

Blascovich, J., Seery, M. D., Mugridge, C. A., Norris, R. K., \& Weisbuch, M. (2004). Predicting athletic performance from cardiovascular indexes of challenge and threat. Journal of Experimental Social Psychology, Vol. 40, 683-688.

Bolger, R. L., Davis, A., \& Rafaeli, E. (2003). Diary methods: capturing life as it lived. Annual Review of Psychology, Vol. 54, 579-616.

Brophy, J. (2008). Motivating students to learn (2nd ed.). Mahwah, NJ: Lawrence Erlbaum Associates.

Bursal, M. (2013). Longitudinal investigation of elementary students' science academic achievement in 4-8th grades: grade level and gender differences. Educational Sciences, 13(2), 1151-1156.

Cheung, D. (2009). Students' attitudes towards chemistry lessons: the interaction effect between grade level and gender. Research in Science Education, 39, 75-91. 
Csikszentmihalyi, M. (1990). Flow: the psychology of optimal experience. New York: Harper Perennial.

Csikszentmihalyi, M. (1997). Finding flow: the psychology of engagement with everyday life. The masterminds series. New York: Basic Books.

Csikszentmihalyi, M., \& Larson, R. (1987). Validity and reliability of the experience-sampling method. The Journal of Nervous and Mental Disease, 175(9), 526-536.

Csikszentmihalyi, M., \& Schneider, B. (2000). Becoming adult. New York: Basic Books.

DeBacker, T. K., \& Nelson, M. (2000). Motivation to learn science: differences related to gender, class type, and ability. The Journal of Educational Research, 93(4), 245-254.

Eccles, J., \& Wang, M. T. (2012). So what is student engagement anyway? In S. L. Christenson, A. L. Reschly \& C. Wylie (Eds.), Handbook of research on student engagement (pp. 133-145). New York: Springer.

Fairbrother, R. (2000). Strategies for learning. In M. Monk \& J. Osborne (Eds.), Good practice in science teaching: what research has to say (pp. 7-22). Buckingham: Open University Press.

Fredricks, J. A., Blumenfeld, P. C., \& Paris, A. H. (2004). School engagement: potential of the concept, state of the evidence. Review of Educational Research, 74(1), 59-109.

Fullan, M. (2007). The new meaning of educational change (3rd ed.). London: College Press.

Gonzales, P., Williams, T., Jocelyn, L., Roey, S., Kastberg, D., \& Brenwald, S. (2008). Highlights from TIMSS 2007: mathematics and science achievement of U.S. fourth-and eighth-grade students in an international context. Washington, DC: National Center for Education Statistics. Retrieved from http://nces.ed.gov/pubs2009/2009001.pdf.

Grant, H., \& Dweck, C. S. (2003). Clarifying achievement goals and their impact. Journal of Personality and Social Psychology, 85(3), 541-553.

Griffth, A. (2010). Persistence of women and minorities in STEM field majors: Is it the school that matters? Economics of Education Review, Vol. 29, 911-922.

Greenfield, T. A. (1997). Gender- and grade-level differences in science interest and participation. Science Education, 81(3), 259-276.

Hektner, J. M., Schmidt, J. A., \& Csikszentmihalyi, M. (2007). Experience sampling method. Measuring the quality of everyday life. Thousand Oaks, CA: Sage Publications.

Hong, J. L., Shim, K. C., \& Chang, N. K. (1998). A study of Korean middle school students' interest in biology and their implications for biology education. International Journal of Science Education, 2O(8), 989-999.

Jimerson, S. R., Campos, E., \& Greif, J. L. (2003). Toward an understanding of definitions and measures of school engagement and related terms. The California School Psychologist, Vol. 8, 7-27.

Krapp, A. (2002). Structural and dynamic aspects of interest development: theoretical considerations from an ontogenetic perspective. Learning and Instruction, Vol. 12, 383-409.

Krapp, A., \& Prenzel, M. (2011). Research on interest in science: theories, methods, and findings. International Journal of Science Education, 33(1), 27-50.

Kumar, D. D. (1991). A meta-analysis of the relationship between science instruction and student engagement. Educational Review, 43(1), 49-61.

Lavonen, J., Byman, R., Uitto, A., Juuti, K., \& Meisalo, V. (2008a). Students' interest and experiences in physics and chemistry related themes: reflections based on a ROSE-survey in Finland. Themes in Science and Technology Education, 1(1), 7-36.

Lavonen, J., Gedrovics, J., Byman, R., Meisalo, V., Juuti, K., \& Uitto, A. (2008b). Students' motivational orientations and career choice in science and technology: a survey in Finland and Latvia. Journal of Baltic Science Education, 7(2), 86-103.

Lavonen, J., Krzywacki, H., Koistinen, L., Welzel-Breuer, M., \& Erb, R. (2012). In-service teacher education course module design focusing on usability of ICT applications in science education. Nordic Studies in Science Education, 8(2), 138-149.

Lavonen, J., \& Laaksonen, S. (2009). Context of teaching and learning school science in Finland: Reflections on PISA 2006 results. Journal of Research in Science Teaching, 46(8), 922-944. 
Lavonen, J., Meisalo, V., Byman, R., Uitto, A., \& Juuti, K. (2005). Pupil interest in physics: a survey in Finland. Nordic Studies in Science Education, Vol. 2, 72-85.

Malmberg, L. E., Hagger, H., Burn, K., Mutton, T., \& Colls, H. (2010). Observed classroom quality during teacher education and two years of professional practice. Journal of Educational Psychology (Nov. 2010), 916-932.

Meijen, C., Jones, M. V., McCarthy, P. J., Sheffield, D., \& Allen, M. S. (2013). Cognitive and affective components of challenge and threat states. Journal of Sports Sciences, 31(8), 847-855.

Muukkonen, H., Hakkarainen, K., Inkinen, M., Lonka, K., \& Salmela-Aro, K. (2008). CASS methods and tools for investigating higher education knowledge practices. In International perspectives in the learning sciences: cre8ing a learning world, proceedings of the Eighth International Conference for the Learning Sciences (Vol. 2, pp. 107-114). Utrecht, The Netherlands: International Conference for the Learning Sciences.

Nakamura, J., \& Csikszentmihalyi, M. (2002). The concept of flow. In C. R. Snyder \& S. J. Lopez (Eds.), Handbook of positive psychology (pp. 89-105). Oxford: Oxford University Press.

Oon, P. T., \& Subramaniam, R. (2010). On the declining interest in physics among students - from the perspective of teachers. International Journal of Science Education, 33(5), 727-746.

Osborne, J., Simon, S., \& Collins, S. (2003). Attitude towards science: a review of the literature and its implications. International Journal of Science Education, 25(9), 1049-1079.

Oscarsson, M., Jidesjö, A., Strömdahl, H., \& Karlsson, K. G. (2009). Science in society or science in school: Swedish secondary school science teachers' beliefs about science and science lessons in comparison with what their students want to learn. Nordic Studies in Science Education, 5(1), 18-34.

Riegle-Crumb, C., \& Moore, C. (2014). The gender-gap in high school physics: Considering the context of local communities. Social Science Quarterly 95(1), 253-268.

Schaufeli, W. H., Martínez, I. M., Pinto, A. M., Salanova, M., \& Bakker, A. B. (2002). Burnout and engagement in university students. A cross-national study. Journal of Cross-Cultural Psychology, 33(5), 464-481.

Schiefele, U. (1992). Topic interest and levels of text comprehension. In K. A. Renninger, S. Hidi \& A. Krapp (Eds.), The role of interest in learning and development (pp. 151-182). Hillsdale, NJ: Erlbaum.

Schiefele, U. (1999). Interest and learning from text. Scientific Studies of Reading, Vol. 3, 257-279.

Schraw, G., \& Lehman, S. (2001). Situational interest: a review of the literature and directions for future research. Educational Psychology Review, 13(3), 23-52.

Seery, M. D. (2011). Challenge or threat? Cardiovascular indexes of resilience and vulnerability to potential stress in humans. Neuroscience and Biobehavioral Reviews, 35, 1603-1610.

Shernoff, D. J., \& Csikszentmihalyi, M. (2009). Cultivating engaged learners and optimal learning environments. In R. Gilman, E. S. Huebner \& M. J. Furlong (Eds.), Handbook of Positive Psychology in Schools (pp. 131-145). New York: Routledge.

Shernoff, D. J., Csikszentmihalyi, M., Schneider, B., \& Shernoff, E. S. (2003). Student engagement in high school classrooms from the perspective of flow theory. School Psychology Quarterly, 18(2), $158-176$.

Singh, K., Granville, M., \& Dika, S. (2002). Mathematics and science achievement: effects of motivation, interest, and academic engagement. The Journal of Educational Research, 95(6), 323-332.

Steinkamp, M. W., \& Maehr, M. L. (1984). Gender differences in motivational orientations toward achievement in school science: a quantitative synthesis. American Educational Research Journal, 21(1), 39-54.

Tolvanen, A., Kiuru, N., Hakkarainen, K., Lonka, K., Inkinen, M., \& Salmela-Aro, K. (2011). Estimation of nonlinear growth component in multilevel modeling: a research application in the daily dynamics of competence, challenge and affects. International Journal of Behavioral Development, Vol. 35, 370-379.

Trumper, R. (2006). Factors affecting junior high school students' interest in biology. Science Education International, 17(1), 31-48. 
Tytler, R., Osborne, J., Williams, G., Tytler, K., \& Cripps, C. J. (2008). Opening up pathways: engagement in STEM across the primary-secondary school transition. Canberra: Australian Department of Education, Employment and Workplace Relations.

Uitto, A. (2014). Interest, attitude, and self-efficacy beliefs explaining upper-secondary school students' orientation towards biology-related careers. International Journal of Science and Mathematics Education, 12, 1425-1444.

Uitto, A., Juuti, K., Lavonen, J., \& Meisalo, V. (2006). Students' interest in biology and their out-ofschool experiences. Journal of Biological Education, 4O(3), 124-129.

Uitto, A., \& Kärnä, P. (2014). Teaching methods enhancing grade nine students' performance and attitudes towards biology. In Education Research For Evidence-based Teaching and Coherence in Learning. Part 2 (co-ed. J. Lavonen \& A. Zeyer), (pp- 67-73), Nicosia, Cyprus: European Science Education Research Association. ISBN: 978-9963-700-77-6

Upadayaya, K., \& Salmela-Aro, K. (2013). Development of school engagement in association with academic success and well-being in varying social context. European Psychologist, 18(2), 136-147.

Vesterinen, V. M., Aksela, M., \& Rantaniitty, T. (2013). Miksi kemiaa opiskellaan ja miksi ei? Perusteluita lukion syventävien kurssien valinnalle [Why do upper secondary school students study chemistry-and why they do not?]. LUMAT, 1(1), 43-54.

Williams, C., Stanisstrect, M., Spall, K., Boyes, E., \& Dickson, D. (2003). Why aren't secondary students interested in physics? Physics Education, 38(4), 324-329.

Wigfield, A., \& Gambria, J. (2010). Students' achievement values, goal orientations and interest: definitions, development, and relations to achievement outcomes. Developmental Review, Vol. 30 , $1-35$. 